\title{
Gamma delta T cells recognize haptens and mount a hapten-specific response
}

\author{
Xun Zeng ${ }^{1 \dagger}$, Christina Meyer ${ }^{2 \dagger \S}$, Jun Huang ${ }^{1 \neq \pi}$, Evan W Newell ${ }^{1 \neq \#}$, Brian A Kidd ${ }^{1 \neq \|}$, \\ Yu-Ling Wei ${ }^{1}$, Yueh-hsiu Chien ${ }^{1,2 *}$
}

1Department of Microbiology and Immunology, Stanford University, Stanford, United
States; ${ }^{2}$ Program in Immunology, Stanford University, Stanford, United States

*For correspondence: chien@ stanford.edu

tThese authors contributed equally to this work

tThese authors also contributed equally to this work

Present address: ${ }^{\S}$ Department of Immuno-Oncology, EMD Serono Research and Development Institute, Billerica, United States; "Institute for Molecular Engineering, University of Chicago, Chicago, United States; "Singapore Immunology Network, Singapore, Singapore; "Department of Genetics and Genomic Sciences, Icahn Institute for Genomics and Multiscale Biology, Ichan School of Medicine at Mount Sinai, New York, United States

Competing interests: The authors declare that no competing interests exist.

Funding: See page 11

Received: 09 June 2014 Accepted: 25 August 2014 Published: 25 September 2014

Reviewing editor: Xuetao Cao, Zhejiang University School of Medicine, China

(c) Copyright Zeng et al. This article is distributed under the terms of the Creative Commons Attribution License, which permits unrestricted use and redistribution provided that the original author and source are credited.

\begin{abstract}
The ability to recognize small organic molecules and chemical modifications of host molecules is an essential capability of the adaptive immune system, which until now was thought to be mediated mainly by B cell antigen receptors. Here we report that small molecules, such as cyanine 3 (Cy3), a synthetic fluorescent molecule, and 4-hydroxy-3-nitrophenylacetyl (NP), one of the most noted haptens, are $ү \delta \bar{T}$ cell antigens, recognized directly by specific $\gamma \delta$ TCRs. Immunization with Cy3 conjugates induces a rapid Cy3-specific y $\delta$ T cell IL-17 response. These results expand the role of small molecules and chemical modifications in immunity and underscore the role of $y \delta \bar{T}$ cells as unique adaptive immune cells that couple B cell-like antigen recognition capability with $\mathrm{T}$ cell effector function.

DOI: 10.7554/eLife.03609.001
\end{abstract}

\section{Introduction}

The adaptive immune system consists of $B$ cells, $\alpha \beta T$ cells and $y \delta T$ cells. While $\alpha \beta T$ cells perform all well-defined functions attributed to T cells, $\gamma \delta T$ cells and $\alpha \beta T$ cells are present together in all but the most primitive vertebrates. This suggests that each cell type performs unique functions and that both are necessary for host immune competence. Indeed, although $\gamma \delta T$ cells and $\alpha \beta T$ cells have similar effector functions, $\gamma \delta$ T cells and $\alpha \beta$ T cells are distinct in their antigen recognition and activation requirements and in their antigen-specific repertoire and effector function development. These differences underlie $ү \delta$ T cells' unique contribution to host immune defense (Chien et al., 2014).

Diversity in antigen receptor specificity is the hallmark of the adaptive immune system. Serological analysis of small chemical compound immune recognition was one of the earliest experimental demonstrations that B cells can mount responses to diverse antigens with specificity (Landsteiner and van der Scheer, 1931; Landsteiner and Chase, 1937). Haptens were characterized as small organic molecules which, when conjugated to a protein, induce a strong hapten-specific B cell response. Since then, antibody responses to haptens have been used extensively to investigate antibody affinity maturation, germinal center formation, and the development of memory B cell responses (Jack et al., 1977; Jacob et al., 1991; McHeyzer-Williams and McHeyzer-Williams, 2005). Antibodies specific for pathogen-produced small compounds and chemical modifications of host molecules have also served as a means of pathogen surveillance (Daneshvar et al., 1989; Temmerman et al., 2004) and to monitor injury or altered physiological states (Vossenaar et al., 2004; Kim et al., 2006; Yang and Sauve, 2006). Thus, small molecule recognition is an important capability of the adaptive immune system.

Although hapten-specific $\alpha \beta T$ cells have been reported and studied in the context of suppressor T cell function, as exemplified by the work of Dorf et al. (Sherr and Dorf, 1981), interaction between the T cell receptor (TCR) and the hapten ligand has not been demonstrated. Moreover, it is well established that the antigen-specific repertoires of peripheral $\alpha \beta T$ cells are largely limited to peptides that are processed from protein antigens in complex with the host major histocompatability complex (MHC) molecules (Huseby et al., 2005; Van Laethem et al., 2007). This restriction on antigen specificity 
eLife digest Our immune system responds to invading microbes-such as viruses and bacteria-and tries to eliminate the threat via two distinct but connected systems: the innate and the adaptive immune systems. Cells of the innate immune system patrol our organs and tissues in an effort to identify and eliminate threats with a quick but general response, which is similar for many different pathogens. This first line of defense also escalates the immune response by activating the adaptive immune system.

Unlike the innate immune response, the adaptive immune response targets unique molecules of different sizes, shapes and chemical compositions-ranging from small organic molecules to large pathogens. The adaptive immune system consists of three types of immune cells: B cells, alpha beta $(\alpha \beta) T$ cells and gamma delta $(\gamma \delta)$ T cells. These cells have proteins on their surfaces that function as receptors; when the receptors recognize and bind to a foreign molecule (called antigen), the cell becomes activated. This then triggers a cascade of events that help to clear the infection and help immune cells to rapidly respond to any future infection by the same pathogen. $\alpha \beta T$ cells and $\gamma \delta$ T cells respond to different triggers, but perform similar tasks-while B cells perform tasks that are different from those of T cells. An effective immune response often involves both B cells and T cells.

One important way that the adaptive immune system can identify an invading microbe or monitor for damaged or abnormal cells is by recognizing chemicals produced by pathogen and chemical modifications of host molecules. And while $B$ cells are able to do this, $\alpha \beta T$ cells are not.

Zeng et al. now show that $\gamma \delta$ T cells can also recognize and mount response against this type of antigen. $ү \delta \mathrm{T}$ cells were shown to detect both a small synthetic fluorescent dye, and a chemical modification that has been extensively studied for $B$ cell responses over the last 80 years. Following on from these findings, the next challenge is to identify $\gamma \delta$ T cells that recognize molecules or chemical compounds produced during infection or disease, and to define these cells' role in immunity. DOI: 10.7554/eLife.03609.002

is a consequence of the thymic development process (Van Laethem et al., 2012). Thus, adaptive immune recognition of small molecules seems to be mainly mediated by $B$ cells rather than $T$ cells.

While $\gamma \delta T$ cells, like $\alpha \beta T$ cells, require thymic maturation before entering the periphery (Ohno et al., 1993), this process does little to constrain the $ү \delta$ T cell antigen-specific repertoire (Jensen et al., 2008). In addition, although fetal-derived $ү \delta$ T cells in murine skin and the reproductive tract express non-variant TCRs, adult human and murine $y \delta$ T cells in other lymphoid compartments (blood, lymph node, spleen, and intestine) express diverse TCRs (Chien et al., 2014). Analysis of y $\delta$ TCR CDR3 sequence diversity and length distribution suggest that these $T$ cells have extensive antigen recognition capability and that as a group, $ү \delta$ TCRs are more similar to immunoglobulins (lgs) than to $\alpha \beta$ TCRs (Rock et al., 1994). Since the requirements of $\gamma \delta \mathrm{T}$ cell antigen recognition are similar to those of $B$ cells, we investigated whether $y \delta$ T cells, like B cells, can recognize haptens.

Here, we report that Cyanine 3 (Сy3), a synthetic fluorescent molecule, is a $y \delta$ T cell antigen, recognized directly by specific $y \delta$ TCRs. Immunization with Cy3 induces y $\delta$ T cells to mount a Cy3-specific IL-17 response. IL-17 is a T cell cytokine, which is essential in the initiation of the inflammatory response. We also identified $y \delta$ TCRs specific for 4-hydroxy-3-nitrophenyl acetyl (NP), one of the most commonly studied haptens in investigation of antibody response. These results enlarge the scope of the $\gamma \delta T$ cell antigen-specific repertoire and suggest a way for this category of antigens to induce a T cell response.

\section{Results}

\section{Cyanine $3(С y 3)$ is a $ү \delta \mathrm{T}$ cell antigen}

To test whether $y \delta$ T cells can recognize small molecules, we chose Cyanine 3 (Cy3) for analysis. Cy3 is a synthetic dye with two modified indole groups joined by a polymethine chain (Figure 1A). It is highly fluorescent and can be used for FACS analysis directly.

Cy3 tetramer ( $\mathrm{Cy}_{3} \mathrm{SAv}$ ) (a recombinant mutant of streptavidin (Ramachandiran et al., 2007) labeled with four $\mathrm{Cy} 3$ molecules at the $\mathrm{C}$-terminal cysteine in each of the four identical subunits) 
A<smiles>[R]N1C(=CC=CC2=[N+]([R])c3ccccc3C2)Cc2ccccc21</smiles>

Cyanine 3 (Сy3)

C

\section{Cy3-MCC SA}

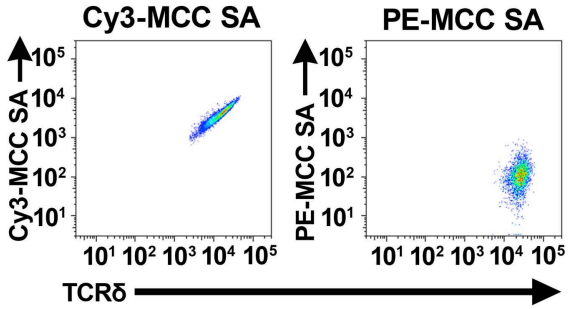

E

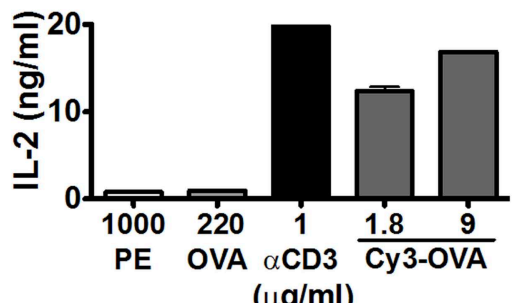

G

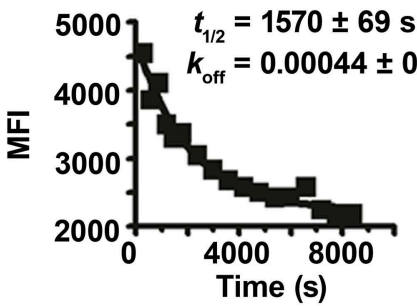

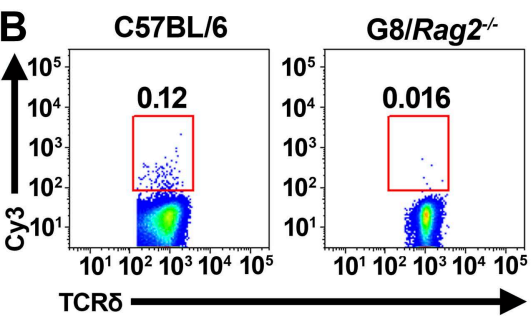

D - Су3-MCc SA - Cy3-BSA -Cy3-OVA

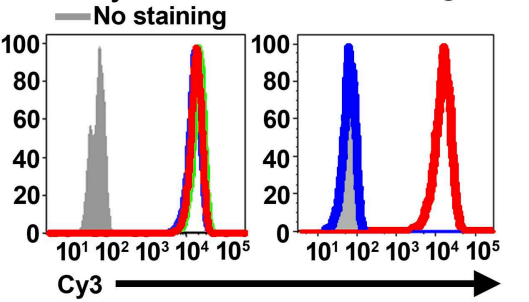

Су3

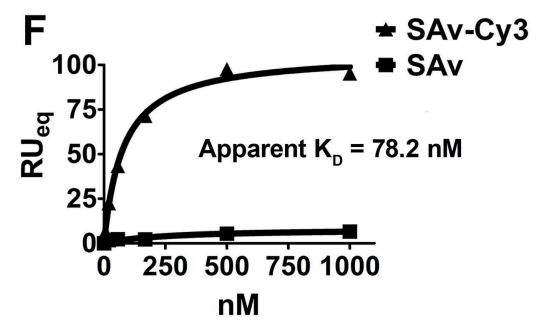

Figure 1. Cy3 is a yס T cell antigen. (A) Chemical structure of Cyanine 3 (Cy3). FACS analysis of (B) Cy3 tetramer $\left(\mathrm{Cy}_{4}-\mathrm{SAv}\right)$ staining of splenic $\gamma \delta \mathrm{T}$ cells in the presence of 10 -fold molar excess of moth cytochrome $c$ peptide coupled SAv (MCC 4 -SAv); (C) NX6/58a- $\beta$ - cells stained with Cy3-MCC-SAv or PE-MCC-SAv; (D) NX6/58a- $\beta$ - cells stained with Cy3-MCC-SAv in the absence (left), or presence of anti-Cy3 Fab (right). (E) IL-2 production by NX6/58a- $\beta$ - cells activated by the indicated amount of plate-bound Cy3-OVA, OVA, PE, anti-CD3 for 16 hr. (F) The saturating binding curves of $\mathrm{Cy}_{3}{ }_{4}-\mathrm{SAv}$ and un-conjugated $\mathrm{SAv}$ to a soluble form of $\mathrm{NX} 6$ as determined by surface plasmon resonance. No detectable binding was observed for $1 \mathrm{mM}$ applications of PE or BSA (not shown).

(G) Kinetics of $\mathrm{Cy}_{3}{ }_{4} \mathrm{SAv}$ binding to $\mathrm{NX6} / 58 \alpha-\beta$ - cells. $t_{1 / 2}$ was determined using real time flow cytometry in the presence of anti-Cy3 antibody Fab fragments (left). $K_{D}$ was determined from Scatchard analysis (right). All results are representative of at least three independent experiments.

DOI: 10.7554/eLife.03609.003

The following figure supplements are available for figure 1:

Figure supplement 1. NX6/58 $\alpha$ - $\beta$ - cells stained with different fluorescently labeled ovalbumin preparations. DOI: 10.7554/eLife.03609.004

Figure supplement 2. Correlation between the mean fluorescence intensities of PE-SAv and $\mathrm{Cy}_{4} \mathrm{SAv}$ on red blood cells. DOI: 10.7554/eLife.03609.005 


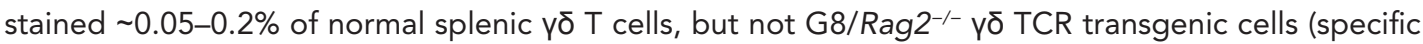
for the nonclassical MHC class I T10 and T22) (Bluestone et al., 1988; Schild et al., 1994; Figure 1B). We then identified Cy3-specific $ү \bar{\delta}$ TCRs on a single cell level by sorting these cells and sequencing their TCR genes. 58a- $\beta$ - cells expressing Cy3-specific y $\delta$ TCRs bound Cy3-ovalbumin (Cy3-OVA), Cy3bovine serum albumin (Cy3-BSA), Cy3-MCC-streptavidin (moth cytochrome C (MCC)-derived peptide, Cy3-labeled at the $\mathrm{N}$-terminus, biotinylated at the $\mathrm{C}$-terminus, and tetramerized with streptavidin), but not FITC or APC labeled OVA, nor PE-MCC peptide/streptavidin (Figure 1C, Figure 1-figure supplement 1; Table 1). Moreover, Cy3-MCC-streptavidin staining of a Cy3-specific үठ TCR NX6/58 $\alpha-\beta$ - was inhibited by the inclusion of Fab fragments of an anti-Cy3 antibody (clone A-6; Santa Cruz Biotechnology) (Figure 1D). In addition, NX6/58 $\alpha-\beta$ - cells were activated by plate-bound Cy3-OVA, but not unmodified OVA (Figure 1E). Binding of the soluble form of a Cy3-specific $ү \delta$ TCR (NX6) to Cy $3_{4} S A v$ can be demonstrated by surface plasmon resonance (Biacore) with an apparent $K_{D}$ of $78.2 \mathrm{nM}$ (Figure 1F). We also examined the affinity of $\mathrm{Cy}_{4}{ }_{4} \mathrm{SAv}$ binding to NX6 expressed on $58 \alpha-\beta$ - cells. Scatchard analysis showed an apparent nanomolar $\mathrm{K}_{\mathrm{D}}(1.8 \mathrm{nM})$ with a half-life of $\sim 26 \mathrm{~min}$ (Figure 1G). Taken together, these results indicate that Сy3 is an antigen of $ү \delta$ T cells, recognized directly by specific $ү \delta$ TCRs.

\section{үठ T cells mount a hapten-specific response}

To determine whether $ү \delta \bar{T}$ cells can mount a hapten-specific response, we immunized mice subcutaneously with Cy3-chicken gamma globulin (Cy3-CGG) in aluminum hydroxide (alum) and analyzed Cy3-specific $ү \delta \mathrm{T}$ cells in the draining lymph nodes with a Cy3-OVA staining reagent. For comparison, we also analyzed Cy3-specific $ү \delta$ T cells in mice immunized with CGG/alum. Alum was used because it is a non-antigenic adjuvant (Eisenbarth et al., 2008), and we chose subcutaneous immunization because it focuses the immune response to the draining lymph nodes.

We found that prior to immunization, $280 \%$ of Cy3-specific $y \delta ~ T$ cells in the lymph nodes were CD44', a phenotype typical of naïve T cells. Within $24 \mathrm{hr}$ after immunization, Cy3-specific $ү \delta$ T cells up-regulated CD44 in Cy3-CGG-immunized mice, but not in CGG-immunized mice (Figure 2A). BioMark analysis showed that Cy3-specific $ү \delta$ T cells express the mRNA coding for RORyt, IL-17A and IL-17F $60 \mathrm{hr}$ after immunization (Figure 2B). Consistent with this observation, analysis of Cy3-specific үठ T cell responses in IL-17F reporter mice (II-17f Thy1.1/Thy1.1) (Lee et al., 2009) and staining showed that $60 \mathrm{hr}$ after Cy3-CGG immunization, activated Cy3-specific $ү \delta$ T cells expressed the Thy1.1 reporter or IL-17 protein (Figure 2C). In addition, we found that activated Cy3-specific $ү \delta$ T cells expressed the receptors for IL-1 and IL-23 (Figure 2B), a characteristic similar to our analysis of activated PE-specific үठ T cells in an immune response (Zeng et al., 2012). The expression of inflammatory cytokine receptors allows antigen-activated $y \delta \mathrm{T}$ cells to integrate signals from antigen receptors and cytokine receptors to mount an enhanced and sustained response (Zeng et al., 2012).

Taken together, the observations that Cy3-specific $ү \delta$ T cells can be activated and produce IL-17 upon Cy3-CGG, but not CGG, immunization indicates that $ү \delta T$ cells, like B cells, are capable of mounting specific responses to small molecules.

\section{4-hydroxy-3-nitrophenyl acetyl (NP) is a $ү \delta ~ T$ cell antigen}

To test the generality of the observation that $y \delta T$ cells can recognize small molecules, we chose 4-hydroxy-3-nitrophenyl acetyl (NP) for analysis. NP is one of the most commonly studied hapten

Table 1. TCR sequences of Cy3 and NP-specific yס TCRs

\begin{tabular}{|c|c|c|c|c|c|c|c|c|c|c|c|c|c|}
\hline & & & V $\delta$ & $\mathbf{N}$ & D1 & $\mathbf{N}$ & D2 & $\mathbf{N}$ & Jర & & $\mathbf{v}_{Y}$ & $\mathbf{N}$ & Jy \\
\hline \multirow[t]{2}{*}{ Су3 } & NX6 & Vס8 & CAAS & & & & & A & T D K & $v_{\gamma} 1$ & $C A V W$ & S R & SGTSWVK \\
\hline & C5 & Vס6A & CALWEL & G & & & G G I R & A S & D K & $v_{\gamma} 1$ & CAVW & TR & GTSWVK \\
\hline \multirow[t]{3}{*}{ NP } & $1 \mathrm{G} 9$ & Vס4 & CALMER & $\mathbf{R}$ & & G Y & R R D T & R A & D K & Vy4 & CSYGS & Y & S SGFHK \\
\hline & $1 \mathrm{E} 3$ & V $\delta 6 \mathrm{~B}$ & CALSEL & G G & & & G G & S A & T D K & $v_{Y} 1$ & $C A \vee W$ & $\mathrm{KKT}$ & G T SWVK \\
\hline & $1 \mathrm{~B} 2$ & Vס4 & CALMER & v & G & LY & R R D T & $S L A$ & TDK & $v_{\gamma} 1$ & CAV & $\mathrm{F}$ & SGTSWVK \\
\hline
\end{tabular}

Each pair of $\gamma$ and $\delta$ chain sequences were identified from a single Cy3 or NP-specific $\gamma \delta$ T cell derived from mouse splenocytes and verified by their ability to confer NP- or Cy3-specific binding to $58 \alpha-\beta$ - cells expressing the TCR.

DOI: 10.7554/eLife.03609.006 


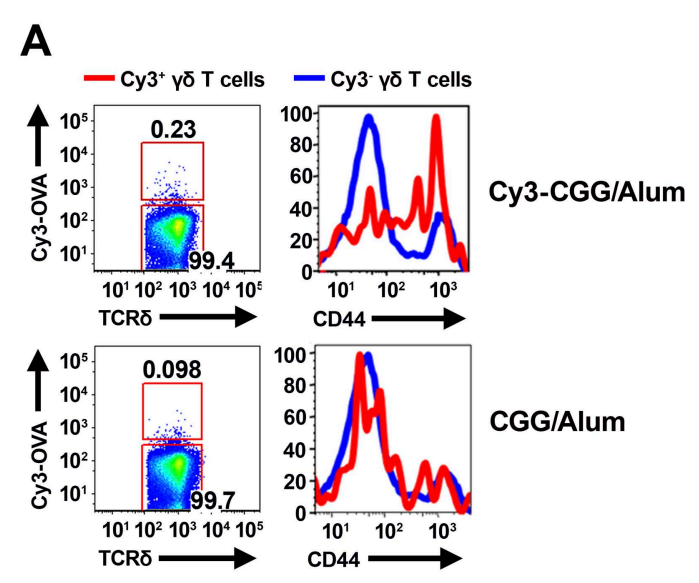

C - ${ }^{-} 3^{+}, \mathrm{CD}^{2} \mathrm{~L}^{10} \mathrm{y} \delta \mathrm{T}$ cells
$-\mathrm{Cy} 3^{+}, \mathrm{CD} 62 \mathrm{~L}^{\text {hi }} \mathrm{y} \delta \mathrm{T}$ cells - Cy3 $3^{-}$ү T cells - Isotype control

$\begin{array}{r}3.30 \\ 0.50 \\ 0.20 \\ 0.10 \\ 0.05 \\ 0.01 \\ \hline \square<0.005\end{array}$

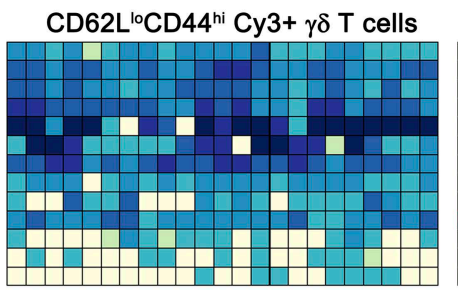

CD62L hi CD44 ${ }^{\text {lo }} \mathrm{Cy3}-\gamma \delta \mathrm{T}$ cells
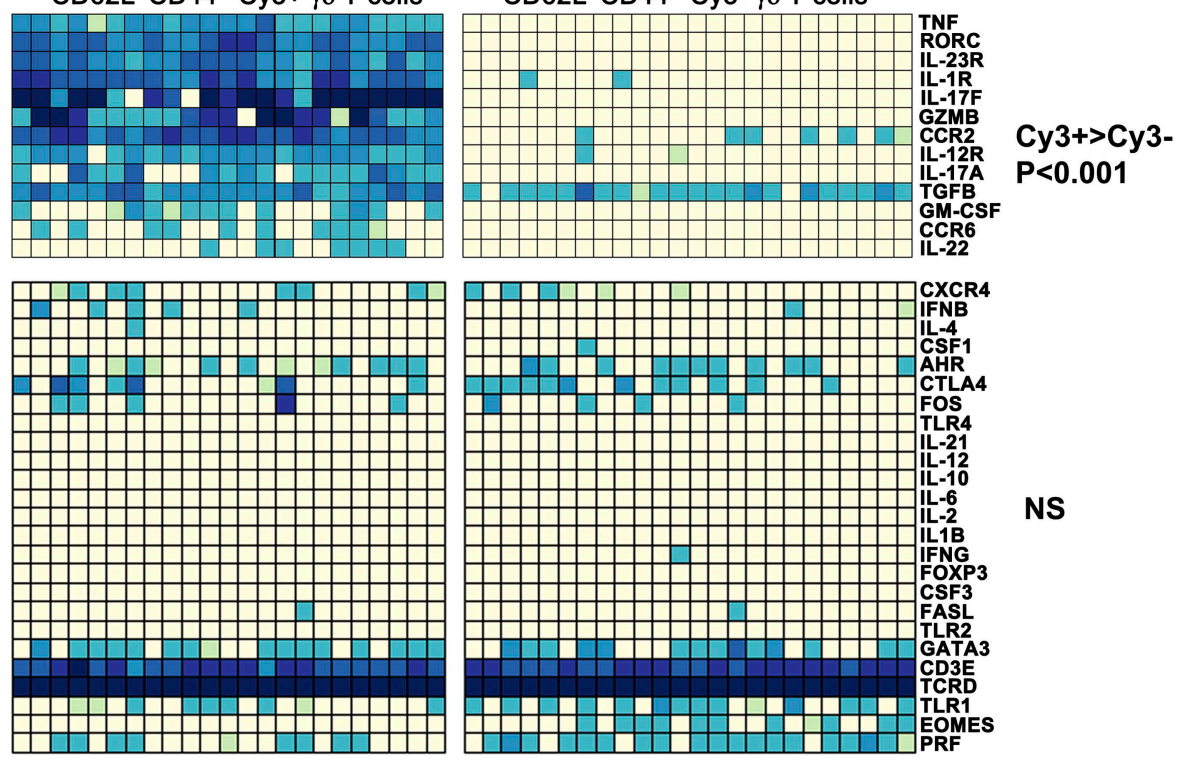

NS

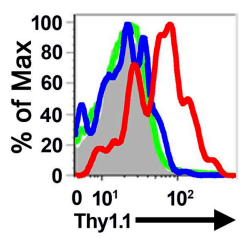

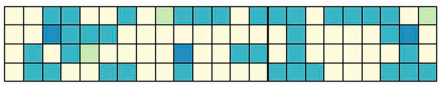

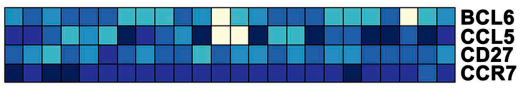

Cy3+<Cy3$P<0.001$

Figure 2. Cy3-specific $ү \delta T$ cell response after immunization. (A) CD44 expression on Cy3-OVA+ (red) and Cy3OVA $^{-} y \delta$ T cells in the draining lymph nodes of mice immunized with Cy3-CGG-alum or CGG-alum 24 hr prior. (B) BioMark analysis of $\mathrm{CD} 62 \mathrm{~L}^{\mathrm{l}} \mathrm{CD} 44^{\text {hi }} \mathrm{Cy} 3^{+}$and $\mathrm{CD} 62 \mathrm{~L}^{\text {hi }} \mathrm{CD} 44^{10} \mathrm{Cy} 3^{-} \mathrm{y} \delta \mathrm{T}$ cells isolated from the draining lymph nodes of C57BL/6 mice immunized with Cy3-CGG $60 \mathrm{hr}$ prior (5 cells/sample). The heatmap, where rows are individual genes and columns are individual samples, indicates the expression or non-expression of a gene/sample pair (relative to the $\beta 2 \mathrm{~m}$ expression). Upper panel shows genes expressing higher $(p<0.001)$ in $\mathrm{Cy} 3^{+}$cells than that in $\mathrm{Cy}^{-}$cells. Middle panel shows non-varying genes. Bottom panel shows genes expressing lower $(p<0.001)$ in $\mathrm{Cy}^{+}{ }^{+}$ cells than that in Cy3- cells. (C) Thy1.1 expression on yo T cells from IL-17f Thy1.1/Thy1.1 mice immunized with Cy3-CGG-alum $60 \mathrm{hr}$ prior, representative of three independent experiments.

DOI: 10.7554/eLife.03609.007

molecules in investigations of antibody responses (Jack et al., 1977; Jacob et al., 1991; McHeyzerWilliams and McHeyzer-Williams, 2005), and NP is structurally unrelated to Cy3 (Figure 3A).

NP conjugated to a fluorescent protein, phycoerythrin (PE), is routinely used to identify NP-specific $B$ cells in FACS analysis. We found that NP-PE stained $\sim 0.14 \%$ of splenic $y \delta ~ T$ cells of normal mice (left panel), but not G8/Rag2 ${ }^{-/-}$y $\delta$ TCR transgenic cells (middle panel). Consistent with the observation that PE is a $ү \delta$ T cell antigen (Zeng et al., 2012), we found $\sim 0.03 \%$ of splenic $ү \delta$ T cells stained with PE under the same staining conditions (right panel). After accounting for background 
A<smiles>O=C(O)Cc1ccc(O)c([N+](=O)[O-])c1</smiles>

4-hyrdoxy-3-nitrophenyl acetyl

B

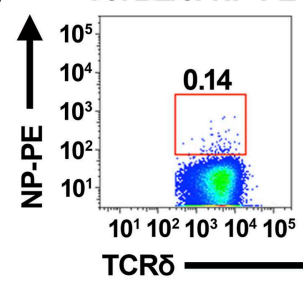

C

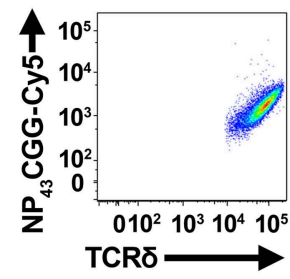

D
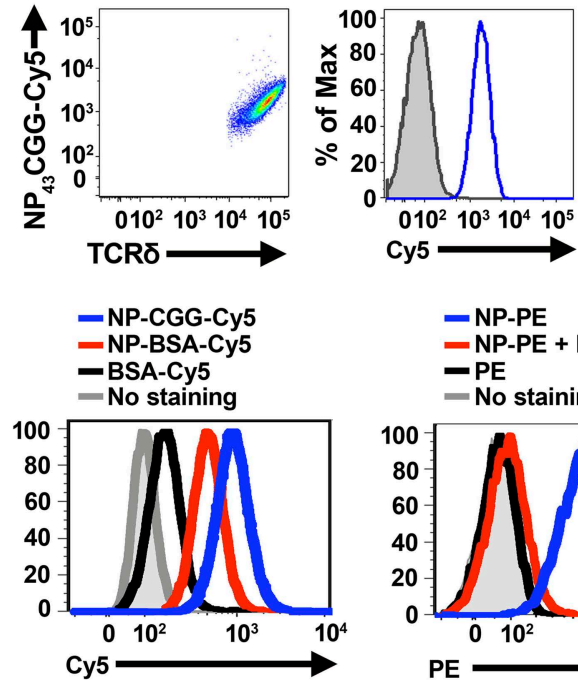

$-\mathrm{NP}_{43} \mathrm{CGG}-\mathrm{Cy} 5$

-CGG-Cy5

C57BL/6: PE
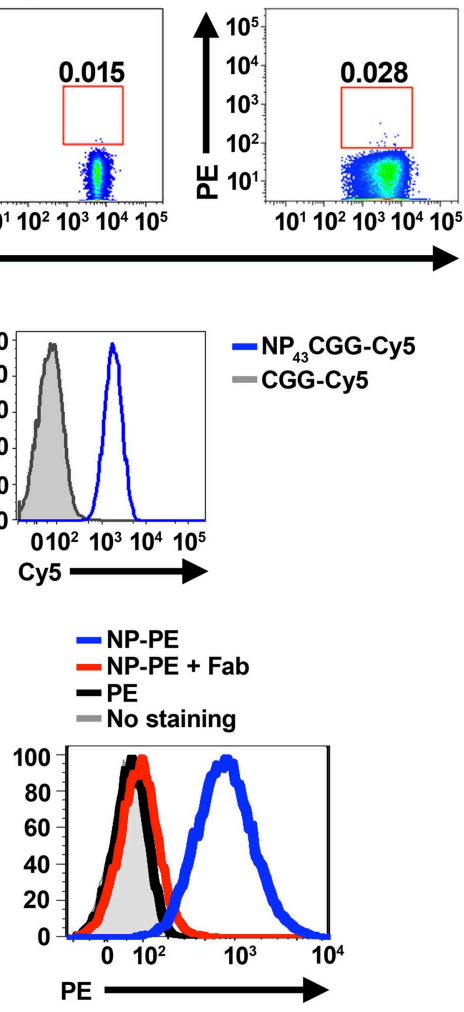

E

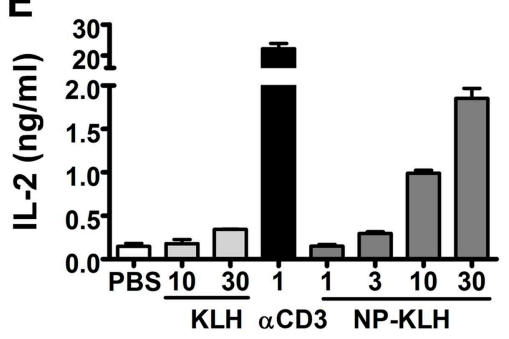

$\mathbf{F}$

$\mu \mathrm{g} / \mathrm{ml}$
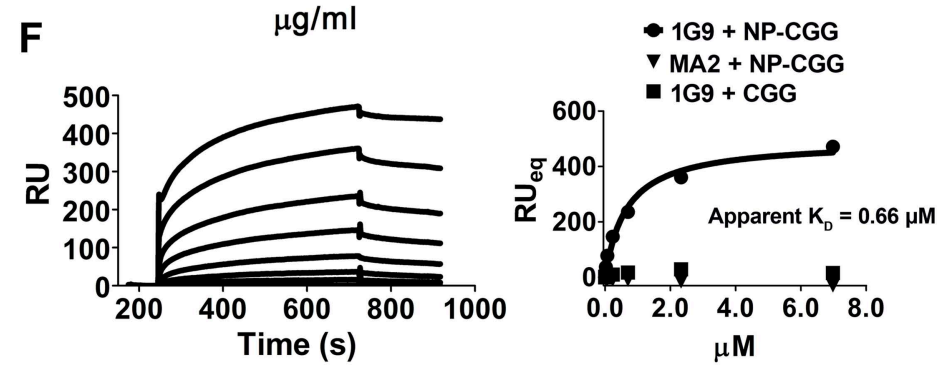

Figure 3. NP is a $y \delta T$ cell antigen. (A) Chemical structure of 4-hydroxy-3-nitrophenyl acetyl (NP). Flow cytometry

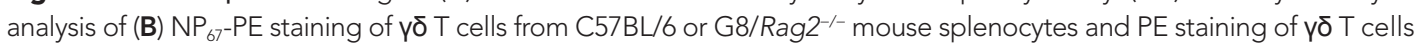
from B6 splenocytes; (C) staining of 58a- $\beta$ - cells expressing an NP-specific $\gamma \delta T C R, 1 G 9$, with $N_{43}-C G G-C y 5$ or Figure 3. Continued on next page 
Figure 3. Continued

CGG-Cy5, showing staining in relation to $\gamma \delta$ TCR expression (left) or as a histogram (right); (D) staining of 58 $\alpha-\beta$ cells expressing an NP-specific yס TCR, 1E3, with NP 43 -CGG-Cy5, NP 26 -BSA-Cy5, or BSA-Cy5 (left) and NP ${ }_{67}-\mathrm{PE}$ alone, $\mathrm{NP}_{67}$-PE with a 20 -fold molar excess of anti-NP Fab, or PE (right). (E) IL-2 production by 1E3/58a- $\beta$ - cells activated by the indicated amount of plate-bound $\mathrm{NP}_{25}-\mathrm{KLH}, \mathrm{KLH}$ (light gray bars), or $0.1 \mu \mathrm{g} / \mathrm{ml}$ anti-CD3. (F) Sensorgram and steady state analysis of $\mathrm{NP}_{43}-\mathrm{CGG}(0-7 \mu \mathrm{M})$ binding to soluble $1 \mathrm{G} 9 \mathrm{TCR}$ measured by surface plasmon resonance. Apparent $K_{D}$ was determined by steady state analysis of SPR measurements (circles). Equal concentrations of un-modified CGG were tested (squares), as well as $\mathrm{NP}_{43}$-CGG with a PE-specific Yठ TCR, MA2 (triangles).

DOI: 10.7554/eLife.03609.008

staining and for PE staining, we estimated that $\sim 0.1 \%$ of total $\gamma \delta T$ cells could be NP-specific (Figure 3B).

We further identified NP-specific $ү \delta$ TCRs on a single cell level. Expressing NP-specific $ү \delta$ TCRs in $58 \alpha-\beta$ - cells enables these cells to be stained with NP-CGG-Cy5, but not CGG-Cy5 (Figure 3C; Table 1). Further investigation showed $58 \alpha-\beta$ - cells expressing NP-specific $\gamma \delta$ TCRs could also be stained with NP-BSA-Cy5 and NP-PE, but not with BSA-Cy5 or PE (Figure 3D, left panel). In addition, NP-PE staining was inhibited by the inclusion of Fab fragments of an anti-NP antibody (clone H33LY; G. Kelsoe) (Figure 3D, right panel). Furthermore, 58a- $\beta$ - cells expressing NP-specific үס TCRs produced IL-2 in response to plate-bound NP-keyhole limpet hemocyanin (NP-KLH), but not plate-bound KLH in a dose-dependent manner (Figure 3E). The observations that only molecules containing the NP conjugation stain NP-specific $y \delta$ TCR-expressing cells, that NP-conjugate staining is blocked by an anti-NP Fab, and that an immobilized NP-conjugate can activate NP-specific $\gamma \delta T$ cells indicate that NP is recognized directly by specific $ү \delta$ TCRs. Indeed, direct binding between soluble NP-specific $ү \delta$ TCRs (1G9) and NP-conjugates was also demonstrated using surface plasmon resonance (Figure 3F). The measured apparent $\mathrm{K}_{\mathrm{D}}$ for the interaction between $\mathrm{NP}_{43}-\mathrm{CGG}$ and the $1 \mathrm{G} 9 \mathrm{TCR}$ was $0.66 \mu \mathrm{M}$. $\mathrm{NP}_{43^{-}}$ CGG exhibited no binding to the PE-specific $ү \delta$ TCR, MA2 (Zeng et al., 2012), and CGG did not bind $1 \mathrm{G} 9$ (Figure 3F). Taken together, these results show that NP is a $ү \delta \mathrm{T}$ cell antigen and is recognized directly by specific $ү \delta$ TCRs.

\section{Discussion}

At the turn of the last century, Landsteiner pioneered the use of small synthetic molecules, known as haptens, to induce an antibody response. When coupled with carrier proteins, haptens induce a strong (hapten) specific, $(\alpha \beta)$ T cell-dependent B cell response. Since the hapten modification provides a defined epitope for analysis of the antibody response, haptenated proteins have been used extensively to characterize the development of B cell responses, and NP is one of the most commonly studied haptens. Although Cy3 has not been used in this context previously, high affinity, isotypeswitched Cy3-specific antibodies are widely available commercially, indicating that Cy3 is also highly immunogenic, similar to other well-studied hapten molecules. Our demonstration that $ү \delta \mathrm{T}$ cells can directly recognize and respond to these molecules represents a significant expansion in the scope of the $ү \delta \mathrm{T}$ cell antigen-specific repertoire.

This is the first demonstration that $ү \delta$ TCRs can interact directly with small molecules. In this context, prior work has shown that a collection of small pyrophosphate-containing organic molecules can stimulate human Vү9Vס2-expressing үס T cells (also referred to as Vү2Vס2 by the Seidman et al. nomenclature) in vitro in a TCR-dependent manner (Chien et al., 2014). These molecules, collectively known as phosphoantigens (pAgs) include isopentenyl pyrophosphate (IPP), an intermediate of the human mevalonate pathway, and (E)-4-hydroxy-3-methyl-but-2-enyl-pyrophosphate (HMBPP), a microbial isoprenoid intermediate. However, recent reports indicate that pAgs do not interact directly with the $ү \delta$ TCR. Instead, VY9Vס2 T cell activation by pAgs is through the recognition of an allosteric change in the extracellular domain of a cell surface molecule, butyrophilin 3A1, which is induced in response to intracellular accumulation of pAg (Wang et al., 2013; Sandstrom et al., 2014).

Our past studies indicate that $ү \delta T$ cells need not encounter cognate antigen in the thymus to signal through the TCR, mature, and exit to the periphery. Peripheral $ү \delta$ T cells derived from $\gamma \delta$ thymocytes that have not previously encountered thymic ligands produce IL-17 upon TCR triggering (Jensen et al., 2008). Indeed, we have identified multiple foreign molecules which are үठ T cell antigens: 
phycoerytherin (PE), a member of the phycobiliprotein family, which is located on the tip of photosynthetic antenna of red algae and cyanobacteria (Zeng et al., 2012), and here, the haptens Cy3 and NP as $ү \delta$ T cell antigens. Moreover, both Cy3 and PE-specific $y \delta ~ T$ cells differentiate toward an IL-17producing phenotype with similar activation kinetics upon antigen encounter (Zeng et al., 2012) (and this manuscript): within $24 \mathrm{hr}$ after immunization, PE- or Cy3 specific үס T cells in the draining lymph node showed activated phenotypes, such as becoming CD44 ${ }^{\mathrm{hi}}$ and $\mathrm{CD} 62 \mathrm{~L}^{\mathrm{l}}$. Activated antigen-specific y $\delta \mathrm{T}$ cells express RORyt $48 \mathrm{hr}$ after immunization and, after another $12 \mathrm{hr}$, IL-17A and IL-17F. Significantly, the expression of inflammatory cytokine receptors such as IL-1R and IL-23R are induced on antigen activated $ү \delta \mathrm{T}$ cells. The cytokine-receptor signaling provides a 'second signal' in addition to TCR engagement to perpetuate the response in inflammation (Zeng et al., 2012).

The inflammatory response is an essential mechanism in the host response to infection and injury. In vertebrates, it requires IL-17, a cytokine primarily made by T cells. IL-17 induces the maturation and release of neutrophils from the bone marrow (Stark et al., 2005). Neutrophil infiltration focuses the immune response at the site of infection or injury, where antigen-specific $\alpha \beta T$ cells subsequently proliferate and gain effector functions after stimulation by professional antigen-presenting cells and a particular cytokine environment. In acute infection, the host must make IL-17 rapidly without prior antigen exposure. The results presented here, together with our previous studies, suggest that $ү \delta$ T cells are uniquely suited for the initial IL-17 response and provide a way for haptens to elicit this important $\mathrm{T}$ cell response. In this context, it has been noted that haptenation enhances the immunogenicity of the carrier protein, but this effect is independent of innate immune recognition and signaling (Palm and Medzhitov, 2009).

While serological responses to haptens were first demonstrated to illustrate the capability of the immune system to recognize diverse antigens, it appears that adaptive immune recognition of haptenlike pathogen-derived organic compounds and chemical modifications of host molecules can serve as a means of pathogen surveillance and monitoring of injury or altered physiological states. The synthetic hapten molecule NP is structurally similar to nitrated tyrosine (3-NTyr). 3-NTyr-containing proteins are formed in the presence of peroxynitrite, one of the side products of reactive oxygen and nitrogen species produced during the early stages of inflammation (Beckman et al., 1992; Ischiropoulos et al., 1992a; Ischiropoulos et al., 1992b; Beckmann et al., 1994). Tyrosine nitration has been demonstrated in a variety of infectious and inflammatory contexts, such as Trypanosoma cruzi infection (Naviliat et al., 2005; Dhiman et al., 2008) and atherosclerosis (Beckmann et al., 1994). There have been reports indicating that these pathological processes are driven in part by IL-17 and үס T cells (Stemme et al., 1991; Kleindienst et al., 1993; Lima and Titus, 1996; Hashmi and Zeng, 2006; Sardinha et al., 2006; Cheng et al., 2008; van Es et al., 2009). Furthermore, the synthetic hapten molecule Cy3 contains two modified indole groups joined by polymethine bonds. The indole molecule is a noted bacterial product and signaling molecule, which accumulates at the site of bacterial infection and affects antibiotic resistance and other virulence factors (Martino et al., 2003; Lee et al., 2007; Hirakawa et al., 2009; Lee et al., 2010; Kim et al., 2011). An indole group also forms the side chain of tryptophan. Altered tryptophan metabolism along the kynurenine pathway and an unrestrained $\gamma \delta \mathrm{T}$ cell IL-17 response were identified as the causes of lethal pulmonary aspergillosis in a mouse model of chronic granulomatous disease (Romani et al., 2008). Whether hapten-specific $ү \delta ~ T$ cells also recognize structurally similar natural products, such as 3-NTyr and indole groups, is unclear. Regardless, our observations that small molecules and chemical modifications on proteins are $ү \delta \top$ cell targets suggest a new category of antigen specificity in addition to cell surface molecules such as the non-classical MHC class I molecules T10 and T22, MHC class I-related chain A/B (MICA/B), and endothelial protein $C$ receptor (EPCR) (Willcox et al., 2012) that can activate $y \delta ~ T$ cells in infection and inflammation.

The role of $y \delta T$ cells in hapten-driven pathological situations is currently unclear, and with these new findings worthy of future study. Allergic contact dermatitis (ACD) represents a specific example of a delayed-type-hypersensitivity response with a hapten-driven mechanism. $\bigvee \delta T$ cells have been implicated in mouse models of ACD. Some studies suggest that $\gamma \delta T$ cells assist $\alpha \beta T$ cells in adoptive transfer of contact sensitivity (Ptak and Askenase, 1992), while others suggest that $ү \delta \bar{T}$ cells regulate effector $\alpha \beta T$ cell responses (Guan et al., 2002). Given our findings that $\gamma \delta T$ cells can recognize haptens and mount a hapten-specific immune response, studies of the role of hapten-specific $\gamma \delta \mathrm{T}$ cells in processes like ACD could yield interesting results.

Although diversity in antigen receptor specificities is the hallmark of the adaptive immune system, effective adaptive immune responses are focused in antigen specificity. This is best illustrated in $\alpha \beta T$ 
cell-dependent antibody responses, wherein only $\alpha \beta T$ cells that can recognize proteins that are internalized and presented by $\mathrm{B}$ cells and displayed as peptide/MHC complexes on cell surface can provide $B$ cell help. Thus, only haptens coupled to proteins, which can be processed and presented for $\alpha \beta T$ cell recognition, can induce a hapten-specific antibody response. While a $\beta \mathrm{T}$ cells are responsible for the development of high affinity, isotype-switched antibodies, we found that $ү \delta T$ cells recognize and respond to noted $B$ cell antigens such as PE, NP and Cy3. In addition, in a case of human autoimmune myositis, where clonally expanded $\gamma \delta T$ cells destroy muscle fiber, the targets of $ү \delta$ T cells were also the targets of autoantibodies known as anti-Jo-1 (Bruder et al., 2012). These observations indicate that an overlap between the $\gamma \delta \mathrm{T}$ cell and B cell antigen-specific repertoires. If the frequencies of other antigen-specific $\gamma \delta \mathrm{T}$ cells were also in a similar range as that of PE, Cy3 and NP, then the numbers of distinct $y \delta T$ cell antigens would be $\sim 10^{3}-10^{4}$. The size of the $B$ cell antigen-specific repertoire was estimated as roughly $10^{5}$, based largely on antigen-specific B cell frequencies of $0.004-0.007 \%$ for nitrophenyl (NP), dinitrophenyl (DNP), and trinitrophenyl (TNP). These values were obtained using antigen-specific spleen foci formation, (Press and Klinman, 1974; Stashenko and Klinman, 1980) and are likely to be underestimates, as this assay requires extensive proliferation of individual clones. In fact, FACS analysis showed that in naïve mice, $0.1 \%$ of the B cells are PE-specific and $0.02 \%$ allophycocyanin (APC)-specific (Pape et al., 2011). Using these values, the size of the antigen-specific B cell repertoire would be $\sim 1000-5000$, in the same range as that estimated for $\gamma \delta \mathrm{T}$ cells. Regardless of the extent of overlap between B cell and $\gamma \delta T$ cell antigen-specific repertoires, our results here support previous observations (Bruder et al., 2012; Zeng et al., 2012) that $\gamma \delta$ T cells and $\beta$ cells can recognise the same antigen. In particular, NP- and PE have been used extensively as model antigens to elucidate principles of antibody affinity maturation, germinal center formation and the development of memory $B$ cell responses. These studies should provide a context to study the roles of $ү \delta \mathrm{T}$ cells in the development of an integrated adaptive immune response.

\section{Materials and methods}

\section{Reagents, mice, and immunization}

Cy3 labeling of biotinylated moth cytochrome c (MCC) peptide (residues 88-103), ovalbumin (OVA) (Sigma, St. Louis, MO), BSA (Sigma), CGG (EMD Millipore, Billerica, MA), and streptavidin (SAv) was carried out with Cy3 maleimide and amine-reactive labeling kits (GE Healthcare, Little Chalfont, UK). NP (4-hydroxy 3-nitrophenylacetyl)-phycoerythrin (PE) was prepared using NP-O succinymidyl ester (NP-OSu) (Biosearch Technologies, Petaluma, CA). NP-chicken gamma globulin (NP-CGG) and NP-bovine serum albumin (NP-BSA) (Biosearch Technologies) were fluorescently labeled with Cyanine 5 (Cy5) on amine groups (Cy5 Mono-Reactive Dye, GE Healthcare).

C57BL/6 mice were purchased from Jackson Laboratories and housed in the Stanford Animal Facility for at least one week before use. IL-17f thy1.1/Thy1.1 mice and G8/Rag ${ }^{-/-}$TCR transgenic mice were bred and housed in the pathogen-free Stanford Animal Facility. All experiments were performed in accordance with the Institutional Biosafety Committee and the Institutional Animal Care and Use Committee. $200 \mu \mathrm{g}$ each of Cy3-CGG and CGG in aluminum hydroxide (Imject Alum; Thermo Scientific, Waltham, MA) per mouse and subcutaneous immunization were used in all studies.

\section{Antibodies and FACS analysis}

Antibodies were purchased from either eBioscience or BD Biosciences unless otherwise stated. All analyses were performed on a BD LSR II flow cytometer. $ү \delta$ T cells were enriched from mouse splenocytes by positive selection as described (Jensen et al., 2008). For NP experiments, staining of enriched үठ T cells was performed using $15 \mu \mathrm{g} / \mathrm{ml} \mathrm{NP}{ }_{43}-C_{-C G}-C y 5$ or $0.02 \mu \mathrm{g} / \mathrm{ml} \mathrm{NP}_{67}-\mathrm{PE}$ or PE, along with PE or APC conjugated anti-TCRס (GL-3), APC-Cy7 and Pacific Blue-labeled antibodies to $\alpha \beta$ TCR (H57-597), B220 (RA2-6B2), F4/80 (BM8), Gr-1 (RB6-8C5), and CD11b (M1/70), and Aqua Amine live/dead stain (Invitrogen Molecular Probes, Eugene, OR). APC-Cy7, Pacific Blue, and Aqua positive cells were excluded from analysis. Anti-NP antibody (clone H33L Y; G. Kelsoe) Fab fragments were prepared using the Pierce Fab Preparation kit. For Cy3 experiments, enriched $\gamma \delta \mathrm{T}$ cells were stained with Cy3conjugated protein $(0.5 \mu \mathrm{M})$ on ice for $1 \mathrm{hr}$, along with APC conjugated GL-3, Aqua Amine, FITC conjugated antibodies to $\alpha \beta$ TCR, B220, CD11b, CD11c (N418), Gr-1, and F4/80. FITC and Aqua-positive cells were excluded from the analysis. 
For the analysis of CD44 expression, enriched $\mathrm{\delta} \delta \mathrm{T}$ cells were stained with FITC-conjugated antibody to CD44 (IM7), APC conjugated GL-3, and Cy3-OVA. For the analysis of Thy1.1 expression on cells isolated from IL-17f thy1.1/Thy1.1 reporter mice, enriched $\gamma \delta$ T cells were stained with FITC conjugated antibody to Thy1.1 (OX-7; Biolegend), Pacific Blue conjugated antibody to CD62L (MEL-14), APC conjugated GL-3, and Cy3-OVA. Both analyses included the addition of Aqua Amine and APC-Cy7 labeled antibodies to $\alpha \beta$ TCR, B220, CD11b, CD11c, Gr-1, and F4/80, with Aqua and APC-Cy7-positive cells excluded from analysis.

\section{Identification of antigen-specific $\gamma \delta$ TCRs, in vitro stimulation assays and ligand binding to TCR expressed on cell surface}

TCRs from Cy3- or NP-specific $ү \delta$ T cells were identified at a single cell level and full length $\mathrm{Y}$ and $\delta$ TCR chain sequences were cloned and expressed in the $58 \alpha-\beta$-cell line as described (Shin et al., 2005;

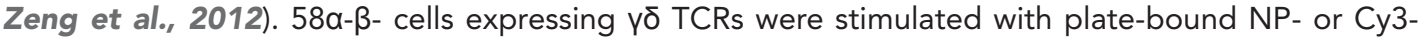
conjugates, the corresponding unmodified protein, or anti-CD3. The supernatant was collected and assayed for IL-2 production as described (Zeng et al., 2012).

Measurement of the kinetics of antigen binding to cell surface-expressed $ү \delta$ TCR by real-time FACS analysis was carried out as described (Zeng et al., 2012). Briefly, 58a- $\beta$ - cells expressing a Cy3-specific y $\delta$ TCR NX6 were stained with $40 \mathrm{nM} \mathrm{Cy3}{ }_{4} \mathrm{SA}$ v for $1 \mathrm{hr}$ at $4^{\circ} \mathrm{C}$. Cells were spun down and resuspended in FACS buffer with 1600 nM anti-Cy3 (clone A-6, Santa Cruz Biotechnology, Dallas, TX) Fab, prepared using the Pierce Fab Preparation Kit. $\mathrm{Cy}_{4}{ }_{4} \mathrm{SAv}$ binding was recorded by flow cytometry over 1.5 to 3 $\mathrm{hr}$ at 5 or $10 \mathrm{~min}$ intervals (<10 s for each measurement). The data were fit using a first-order decay kinetic model to obtain the off-rate $\left(k_{\text {off }}\right)$ and half-life $\left(t_{1 / 2}\right)$.

Scatchard analysis of Cy3 binding to NX6/58 $\alpha$ - $\beta$ - cells was carried out as described in Zeng et al. (2012) with some modifications. $1 \times 10^{5}$ cells were incubated with $27.34-1.71 \mathrm{nM} \mathrm{Cy}{ }_{4} \mathrm{SAv}$. To quantify cell surface bound $\mathrm{Cy}_{4}{ }_{4} \mathrm{SAv}$, we biotinylated red blood cells (RBCs) to generate cells with different surface biotin densities (Huang et al., 2010). The same batch of biotinylated RBCs was stained with either PE-SAv or $\mathrm{Cy}_{4} \mathrm{SAv}$. A linear correlation (Figure 1-figure supplement 2) between the mean fluorescence intensities of PE-SAv and $\mathrm{Cy}_{4}{ }_{4} \mathrm{SAv}$ was constructed, so that the $\mathrm{Cy}{ }_{4} \mathrm{SAv}$ staining intensities could be converted to PE-SAv intensities, which were used to calculate the number of bound ligands by comparing them with the standard PE calibration curve.

\section{Analysis of soluble TCR and ligand interactions}

Soluble $ү \delta$ TCRs were produced as described (Zeng et al., 2012). Briefly, the extracellular domains of the $Y$ and $\delta$ chains (residues 1-273 and 1-242, respectively) were cloned in frame with a gene encoding a rhinovirus protease site, followed by acidic (TCR- $\delta$ ) or basic (TCR- $\gamma$ ) leucine zippers and a (histidine) ${ }_{6}$ tag in the pMSCV-P2 and Z4 retroviral expression vectors. These vectors contain an internal ribosome entry site followed by puromycin resistance gene for $\gamma$ chain or zeocin resistance gene for $\delta$ chain and expressed in BHK-21 cells.

Surface plasmon resonance using the Biacore system was used for quantitative measurements of TCR-ligand interactions. All Biacore measurements were performed on a Biacore 3000 instrument using a CM5 chip. 10,000 RU of anti-TCRס was immobilized using amine linkages; anti-TCR $\beta$ was immobilized as a reference surface. Roughly $300 \mathrm{RU}$ of $ү \delta$ TCR was injected into the system, allowed to stabilize for $1 \mathrm{~min}$, then a range of concentrations of analytes were injected, followed by a $2 \mathrm{~min}$ dissociation time. For NP-specific TCRs, $\mathrm{NP}_{43}-\mathrm{CGG}$ and $\mathrm{CGG}$, were tested; for the Cy3-specific TCR, $\mathrm{Cy}_{4}-\mathrm{SAv}$ and streptavidin were tested. $10 \mathrm{mM}$ glycine $\mathrm{pH} 2.5$ was used at the end of each cycle to remove bound TCR and ligand. Specific binding was assessed by subtracting a blank buffer injection for each cycle. The dose response curves for $\mathrm{NP}_{43}-\mathrm{CGG}, \mathrm{CGG}, \mathrm{Cy} 3_{4}-\mathrm{SAv}$, and unconjugated $\mathrm{SAv}$ for specific binding were measured by averaging signal between 10 and $20 \mathrm{~s}$ at the end of each analyte injection, as very slow unbinding was observed.

\section{BioMark analysis}

Quantitative analysis of transcript expression of Cy3-specific $ү \bar{\delta}$ T cells was carried out with the BioMark system as follows: $60 \mathrm{hr}$ after Cy3-CGG immunization, yס T cells were enriched from the draining lymph nodes of immunized mice, then incubated with Cy3-KLH $(0.5 \mu \mathrm{M})$ for $6 \mathrm{hr}$ in vitro. CD62 $L^{\text {lo } C D 44}{ }^{\text {hi }}$ $\mathrm{Cy}^{+}$and $\mathrm{CD} 62 \mathrm{~L}^{\mathrm{hi}} \mathrm{CD} 44^{\mathrm{lo}} \mathrm{Cy} 3^{-} \mathrm{y} \delta \mathrm{T}$ cells were then FACS sorted into a PCR plate with five cells per well for the analysis. The primers for BioMark qPCR were purchased from Applied Biosystems. The sequences are described in Supplementary file 1. 
Analyses of the expression data were performed with the $\mathrm{R}$ statistical package v.3.0.2. To compare the transcriptional profiles of $\mathrm{Cy}^{+}$and $\mathrm{Cy}^{-}{ }^{-}$cells, we performed differential expression analysis using a two-sample Mann-Whitney test. Prior to hypothesis testing, we removed any gene that did not vary across the entire sample of $\mathrm{Cy}^{+}$and $\mathrm{Cy}^{-}$cells. Genes were considered significantly different at a Bonferroni-corrected p-value $<0.0019$. Gene expression differences were displayed in a two-dimensional heatmap false colored based on transcript expression levels.

\section{Acknowledgements}

We thank P Pereira for the VY1-specific antibody; G Kelsoe for the anti-NP monoclonal antibody; $M$ Birnbaum for TCR purification advice.

\section{Additional information}

Funding

\begin{tabular}{|c|c|c|}
\hline Funder & Grant reference number & Author \\
\hline $\begin{array}{l}\text { Office of Extramural } \\
\text { Research, National } \\
\text { Institutes of Health }\end{array}$ & R21Al107082 & $\begin{array}{l}\text { Xun Zeng, Christina Meyer, } \\
\text { Yueh-hsiu Chien }\end{array}$ \\
\hline $\begin{array}{l}\text { Office of Extramural } \\
\text { Research, National } \\
\text { Institutes of Health }\end{array}$ & RO1Al80829 & $\begin{array}{l}\text { Xun Zeng, Christina Meyer, } \\
\text { Jun Huang, Evan W Newell, } \\
\text { Brian A Kidd, Yu-Ling Wei, } \\
\text { Yueh-hsiu Chien }\end{array}$ \\
\hline $\begin{array}{l}\text { The Burt and Marion } \\
\text { Avery Endowment }\end{array}$ & & $\begin{array}{l}\text { Xun Zeng, Christina Meyer, } \\
\text { Jun Huang, Evan W Newell, } \\
\text { Brian A Kidd, Yu-Ling Wei, } \\
\text { Yueh-hsiu Chien }\end{array}$ \\
\hline $\begin{array}{l}\text { Office of Extramural } \\
\text { Research, National } \\
\text { Institutes of Health }\end{array}$ & U19AI090019 & Yueh-hsiu Chien \\
\hline
\end{tabular}

The funders had no role in study design, data collection and interpretation, or the decision to submit the work for publication.

Author contributions

XZ, CM, JH, EWN, BAK, Y-LW, Conception and design, Acquisition of data, Analysis and interpretation of data, Revising the article; Y-C, Conception and design, Analysis and interpretation of data, Drafting and revising the article

Author ORCIDs

Christina Meyer, (iD http://orcid.org/0000-0002-0380-195X

Ethics

Animal experimentation: All experiments involving animals were performed in accordance with the Institutional Biosafety Committee and the Institutional Animal Care and Use Committee (IACUC) of Stanford University. All animals were handled according to approved IACUC protocols (\#9456 and \#10081). Every effort was made to minimize suffering.

\section{Additional files}

Supplementary file

- Supplementary file 1. Primers used in this study.

DOI: 10.7554/eLife.03609.009

\section{References}

Beckman JS, Ischiropoulos H, Zhu L, van der Woerd M, Smith C, Chen J, Harrison J, Martin JC, Tsai M. 1992. Kinetics of superoxide dismutase- and iron-catalyzed nitration of phenolics by peroxynitrite. Archives of Biochemistry and Biophysics 298:438-445. doi: 10.1016/0003-9861(92)90432-V. 
Beckmann JS, Ye YZ, Anderson PG, Chen J, Accavitti MA, Tarpey MM, White CR. 1994. Extensive nitration of protein tyrosines in human atherosclerosis detected by immunohistochemistry. Biological Chemistry HoppeSeyler 375:81-88. doi: 10.1515/bchm3.1994.375.2.81.

Bluestone JA, Cron RQ, Cotterman M, Houlden BA, Matis LA. 1988. Structure and specificity of T cell receptor gamma/delta on major histocompatibility complex antigen-specific CD3+, CD4-, CD8- T lymphocytes. The Journal of Experimental Medicine 168:1899-1916. doi: 10.1084/jem.168.5.1899.

Bruder J, Siewert K, Obermeier B, Malotka J, Scheinert P, Kellermann J, Ueda T, Hohlfeld R, Dornmair K. 2012. Target specificity of an autoreactive pathogenic human gammadelta-T cell receptor in myositis. The Journal of Biological Chemistry 287:20986-20995. doi: 10.1074/jbc.M112.356709.

Cheng X, Yu X, Ding YJ, Fu QQ, Xie JJ, Tang TT, Yao R, Chen Y, Liao YH. 2008. The Th17/Treg imbalance in patients with acute coronary syndrome. Clinical Immunology 127:89-97. doi: 10.1016/j.clim.2008.01.009.

Chien YH, Meyer C, Bonneville M. 2014. Gammadelta T cells: first line of defense and beyond. Annual Review of Immunology 32:121-155. doi: 10.1146/annurev-immunol-032713-120216.

Daneshvar MI, Brooks JB, Malcolm GB, Pine L. 1989. Analyses of fermentation products of Listeria species by frequency-pulsed electron-capture gas-liquid chromatography. Canadian Journal of Microbiology 35:786-793. doi: 10.1139/m89-131.

Dhiman M, Nakayasu ES, Madaiah YH, Reynolds BK, Wen JJ, Almeida IC, Garg NJ. 2008. Enhanced nitrosative stress during Trypanosoma cruzi infection causes nitrotyrosine modification of host proteins: implications in Chagas' disease. The American Journal of Pathology 173:728-740. doi: 10.2353/ajpath.2008.080047.

Eisenbarth SC, Colegio OR, O'Connor W, Sutterwala FS, Flavell RA. 2008. Crucial role for the Nalp3 inflammasome in the immunostimulatory properties of aluminium adjuvants. Nature 453:1122-1126. doi: 10.1038/ nature06939.

Guan H, Zu G, Slater M, Elmets C, Xu H. 2002. GammadeltaT cells regulate the development of hapten-specific CD8+ effector T cells in contact hypersensitivity responses. The Journal of Investigative Dermatology 119:137-142. doi: 10.1046/j.1523-1747.2002.01830.x.

Hashmi S, Zeng QT. 2006. Role of interleukin-17 and interleukin-17-induced cytokines interleukin-6 and interleukin-8 in unstable coronary artery disease. Coronary Artery Disease 17:699-706. doi: 10.1097/01. mca.0000236288.94553.b4.

Hirakawa H, Kodama T, Takumi-Kobayashi A, Honda T, Yamaguchi A. 2009. Secreted indole serves as a signal for expression of type III secretion system translocators in enterohaemorrhagic Escherichia coli O157:H7. Nature Reviews Microbiology 155:541-550. doi: 10.1099/mic.0.020420-0.

Huang J, Zarnitsyna VI, Liu B, Edwards LJ, Jiang N, Evavold BD, Zhu C. 2010. The kinetics of two-dimensional TCR and PMHC interactions determine T-cell responsiveness. Nature 464:932-936. doi: 10.1038/ nature08944.

Huseby ES, White J, Crawford F, Vass T, Becker D, Pinilla C, Marrack P, Kappler JW. 2005. How the T cell repertoire becomes peptide and MHC specific. Cell 122:247-260. doi: 10.1016/j.cell.2005.05.013.

Ischiropoulos H, Zhu L, Beckman JS. 1992a. Peroxynitrite formation from macrophage-derived nitric oxide. Archives of Biochemistry and Biophysics 298:446-451. doi: 10.1016/0003-9861(92)90433-W.

Ischiropoulos H, Zhu L, Chen J, Tsai M, Martin JC, Smith CD, Beckman JS. 1992b. Peroxynitrite-mediated tyrosine nitration catalyzed by superoxide dismutase. Archives of Biochemistry and Biophysics 298:431-437. doi: 10.1016/0003-9861(92)90431-U.

Jack RS, Imanishi-Kari T, Rajewsky K. 1977. Idiotypic analysis of the response of C57BL/6 mice to the (4-hydroxy-3-nitrophenyl)acetyl group. European Journal of Immunology 7:559-565. doi: 10.1002/ eji.1830070813.

Jacob J, Kassir R, Kelsoe G. 1991. In situ studies of the primary immune response to (4-hydroxy-3-nitrophenyl) acetyl. I. The architecture and dynamics of responding cell populations. The Journal of Experimental Medicine 173:1165-1175. doi: 10.1084/jem.173.5.1165.

Jensen KD, Su X, Shin S, Li L, Youssef S, Yamasaki S, Steinman L, Saito T, Locksley RM, Davis MM, Baumgarth N, Chien YH. 2008. Thymic selection determines gammadelta T cell effector fate: antigen-naive cells make interleukin-17 and antigen-experienced cells make interferon gamma. Immunity 29:90-100. doi: 10.1016/j. immuni.2008.04.022.

Kim SC, Sprung R, Chen Y, Xu Y, Ball H, Pei J, Cheng T, Kho Y, Xiao H, Xiao L, Grishin NV, White M, Yang XJ, Zhao Y. 2006. Substrate and functional diversity of lysine acetylation revealed by a proteomics survey. Molecular Cell 23:607-618. doi: 10.1016/j.molcel.2006.06.026.

Kim YG, Lee JH, Cho MH, Lee J. 2011. Indole and 3-indolylacetonitrile inhibit spore maturation in Paenibacillus alvei. BMC Microbiology 11:119. doi: 10.1186/1471-2180-11-119.

Kleindienst R, Xu Q, Willeit J, Waldenberger FR, Weimann S, Wick G. 1993. Immunology of atherosclerosis. Demonstration of heat shock protein 60 expression and T lymphocytes bearing alpha/beta or gamma/delta receptor in human atherosclerotic lesions. The American Journal of Pathology 142:1927-1937.

Landsteiner K, Chase MW. 1937. STUDIES ON THE SENSITIZATION OF ANIMALS WITH SIMPLE CHEMICAL COMPOUNDS : IV. ANAPHYLAXIS INDUCED BY PICRYL CHLORIDE AND 2:4 DINITROCHLOROBENZENE. The Journal of Experimental Medicine 66:337-351. doi: 10.1084/jem.66.3.337.

Landsteiner K, van der Scheer J. 1931. ON THE SPECIFICITY OF SEROLOGICAL REACTIONS WITH SIMPLE CHEMICAL COMPOUNDS (INHIBITION REACTIONS). The Journal of Experimental Medicine 54:295-305. doi: 10.1084/jem.54.3.295.

Lee J, Jayaraman A, Wood TK. 2007. Indole is an inter-species biofilm signal mediated by SdiA. BMC Microbiology 7:42. doi: 10.1186/1471-2180-7-42. 
Lee HH, Molla MN, Cantor CR, Collins JJ. 2010. Bacterial charity work leads to population-wide resistance. Nature 467:82-85. doi: 10.1038/nature09354.

Lee YK, Turner H, Maynard CL, Oliver JR, Chen D, Elson CO, Weaver CT. 2009. Late developmental plasticity in the T helper 17 lineage. Immunity 30:92-107. doi: 10.1016/j.immuni.2008.11.005.

Lima HC, Titus RG. 1996. Effects of sand fly vector saliva on development of cutaneous lesions and the immune response to Leishmania braziliensis in BALB/c mice. Infection and Immunity 64:5442-5445.

Martino PD, Fursy R, Bret L, Sundararaju B, Phillips RS. 2003. Indole can act as an extracellular signal to regulate biofilm formation of Escherichia coli and other indole-producing bacteria. Canadian Journal of Microbiology 49:443-449. doi: 10.1139/w03-056.

McHeyzer-Williams LJ, McHeyzer-Williams MG. 2005. Antigen-specific memory B cell development. Annual Review of Immunology 23:487-513. doi: 10.1146/annurev.immunol.23.021704.115732.

Naviliat M, Gualco G, Cayota A, Radi R. 2005. Protein 3-nitrotyrosine formation during Trypanosoma cruzi infection in mice. Brazilian Journal of Medical and Biological Research 38:1825-1834. doi: 10.1590/ S0100-879X2005001200011.

Ohno H, Aoe T, Taki S, Kitamura D, Ishida Y, Rajewsky K, Saito T. 1993. Developmental and functional impairment of T cells in mice lacking CD3 zeta chains. The EMBO Journal 12:4357-4366.

Palm NW, Medzhitov R. 2009. Immunostimulatory activity of haptenated proteins. Proceedings of the National Academy of Sciences of USA 106:4782-4787. doi: 10.1073/pnas.0809403105.

Pape KA, Taylor JJ, Maul RW, Gearhart PJ, Jenkins MK. 2011. Different B cell populations mediate early and late memory during an endogenous immune response. Science 331:1203-1207. doi: 10.1126/science.1201730.

Press JL, Klinman NR. 1974. Frequency of hapten-specific B cells in neonatal and adult murine spleens. European Journal of Immunology 4:155-159. doi: 10.1002/eji.1830040302.

Ptak W, Askenase PW. 1992. Gamma delta T cells assist alpha beta T cells in adoptive transfer of contact sensitivity. The Journal of Immunology 149:3503-3508.

Ramachandiran V, Grigoriev V, Lan L, Ravkov E, Mertens SA, Altman JD. 2007. A robust method for production of MHC tetramers with small molecule fluorophores. Journal of Immunological Methods 319:13-20. doi: 10.1016/j. jim.2006.08.014.

Rock EP, Sibbald PR, Davis MM, Chien YH. 1994. CDR3 length in antigen-specific immune receptors. The Journal of Experimental Medicine 179:323-328. doi: 10.1084/jem.179.1.323.

Romani L, Fallarino F, De Luca A, Montagnoli C, D'Angelo C, Zelante T, Vacca C, Bistoni F, Fioretti MC, Grohmann U, Segal BH, Puccetti P. 2008. Defective tryptophan catabolism underlies inflammation in mouse chronic granulomatous disease. Nature 451:211-215. doi: 10.1038/nature06471.

Sandstrom A, Peigné CM, Léger A, Crooks JE, Konczak F, Gesnel MC, Breathnach R, Bonneville M, Scotet E, Adams EJ. 2014. The intracellular B30.2 domain of butyrophilin 3A1 binds phosphoantigens to mediate activation of human Vgamma9Vdelta2 T cells. Immunity 40:490-500. doi: 10.1016/j.immuni.2014.03.003.

Sardinha LR, Elias RM, Mosca T, Bastos KR, Marinho CR, D'Império Lima MR, Alvarez JM. 2006. Contribution of NK, NK T, gamma delta $T$, and alpha beta $T$ cells to the gamma interferon response required for liver protection against Trypanosoma cruzi. Infection and Immunity 74:2031-2042. doi: 10.1128/IAI.74.4.2031-2042.2006.

Schild H, Mavaddat N, Litzenberger C, Ehrich EW, Davis MM, Bluestone JA, Matis L, Draper RK, Chien YH. 1994. The nature of major histocompatibility complex recognition by gamma delta T cells. Cell 76:29-37. doi: 10.1016/0092-8674(94)90170-8.

Sherr DH, Dorf ME. 1981. Hapten-specific T cell responses to 4-hydroxy-3-nitrophenyl acetyl. IX. Characterization of Idiotype-specific effector-phase suppressor cells on plaque-forming cell responses in vitro. The Journal of Experimental Medicine 153:1445-1456. doi: 10.1084/jem.153.6.1445.

Shin S, El-Diwany R, Schaffert S, Adams EJ, Garcia KC, Pereira P, Chien YH. 2005. Antigen recognition determinants of gammadelta T cell receptors. Science 308:252-255. doi: 10.1126/science.1106480.

Stark MA, Huo Y, Burcin TL, Morris MA, Olson TS, Ley K. 2005. Phagocytosis of apoptotic neutrophils regulates granulopoiesis via IL-23 and IL-17. Immunity 22:285-294. doi: 10.1016/j.immuni.2005.01.011.

Stashenko P, Klinman NR. 1980. Analysis of the primary anti-(4-hydroxy-3-nitrophenyl) acetyl (NP) responsive B cells in BALB/C and B10.D2 mice. The Journal of Immunology 125:531-537.

Stemme S, Rymo L, Hansson GK. 1991. Polyclonal origin of T lymphocytes in human atherosclerotic plaques. Laboratory Investigation; A Journal of Technical Methods and Pathology 65:654-660.

Temmerman S, Pethe K, Parra M, Alonso S, Rouanet C, Pickett T, Drowart A, Debrie AS, Delogu G, Menozzi FD, Sergheraert C, Brennan MJ, Mascart F, Locht C. 2004. Methylation-dependent T cell immunity to Mycobacterium tuberculosis heparin-binding hemagglutinin. Nature Medicine 10:935-941. doi: 10.1038/nm1090.

van Es T, van Puijvelde GH, Ramos OH, Segers FM, Joosten LA, van den Berg WB, Michon IM, de Vos P, van Berkel TJ, Kuiper J. 2009. Attenuated atherosclerosis upon IL-17R signaling disruption in LDLr deficient mice. Biochemical and Biophysical Research Communications 388:261-265. doi: 10.1016/j.bbrc.2009.07.152.

Van Laethem F, Sarafova SD, Park JH, Tai X, Pobezinsky L, Guinter TI, Adoro S, Adams A, Sharrow SO, Feigenbaum L, Singer A. 2007. Deletion of CD4 and CD8 coreceptors permits generation of alphabetaT cells that recognize antigens independently of the MHC. Immunity 27:735-750. doi: 10.1016/j.immuni.2007.10.007.

Van Laethem F, Tikhonova AN, Singer A. 2012. MHC restriction is imposed on a diverse T cell receptor repertoire by CD4 and CD8 co-receptors during thymic selection. Trends in Immunology 33:437-441. doi: 10.1016/j. it.2012.05.006.

Vossenaar ER, Després N, Lapointe E, van der Heijden A, Lora M, Senshu T, van Venrooij WJ, Ménard HA. 2004. Rheumatoid arthritis specific anti-Sa antibodies target citrullinated vimentin. Arthritis Research \& Therapy 6:R142-R150. doi: 10.1186/ar1149. 
Wang H, Henry O, Distefano MD, Wang YC, Räikkönen J, Mönkkönen J, Tanaka Y, Morita CT. 2013. Butyrophilin $3 \mathrm{~A} 1$ plays an essential role in prenyl pyrophosphate stimulation of human Vgamma2Vdelta2 $\mathrm{T}$ cells. The Journal of Immunology 191:1029-1042. doi: 10.4049/jimmunol.1300658.

Willcox CR, Pitard V, Netzer S, Couzi L, Salim M, Silberzahn T, Moreau JF, Hayday AC, Willcox BE, Déchanet-Merville J. 2012. Cytomegalovirus and tumor stress surveillance by binding of a human gammadelta T cell antigen receptor to endothelial protein C receptor. Nature Immunology 13:872-879. doi: 10.1038/ ni.2394.

Yang T, Sauve AA. 2006. NAD metabolism and sirtuins: metabolic regulation of protein deacetylation in stress and toxicity. The AAPS Journal 8:E632-E643. doi: 10.1208/aapsj080472.

Zeng X, Wei YL, Huang J, Newell EW, Yu H, Kidd BA, Kuhns MS, Waters RW, Davis MM, Weaver CT, Chien YH. 2012. Gammadelta T cells recognize a microbial encoded B cell antigen to initiate a rapid antigen-specific interleukin-17 response. Immunity 37:524-534. doi: 10.1016/j.immuni.2012.06.011. 